\title{
Successful Adjustment in Botswana ${ }^{1}$
}

\author{
Charles Harvey
}

For the first 10 years after independence in 1966 , Botswana remained a member of the Rand Monetary Area (RMA), using the Rand as its currency and having no central bank of its own.

There were advantages:

(a) Investment from the RMA was encouraged.

(b) Tourism from the RMA was also encouraged, especially by the absence of exchange controls between the two countries.

(c) Individuals and institutions in Botswana, including the commercial banks, were able to invest liquid funds in the Johannesburg money market.

In addition, the Botswana Government could have had a significant and increasing income by staying in the RMA. New arrangements for the RMA were being negotiated in 1975, under which the three smaller states were offered interest on a quite generous estimate of the Rand currently circulating in each country, plus a formula for later growth in currency circulation. Botswana withdrew from the negotiations in order to create an independent monetary system; Lesotho and Swaziland signed the agreement, which applies to the Rand circulating in each country (etimated total circulation, less the amount of local notes and coins issued).

It is possible that the slowdown in economic growth after 1976 was partly caused by reduced foreign investment from the RMA, in turn caused by fears of the effects of the new monetary system. But the main reason for the slowdown was that the economy was between mining construction booms. With stagnant demand there was little incentive to invest.

It is also possible that the growth of tourism was adversely affected, although the number of arrivals from the RMA doubled from 1976 to 1980 . Whatever adverse effects did exist on tourism and investment, they were almost certainly small; and it is unlikely that they diminished over time, as it became clear that the new regime was liberal and likely to remain so. Depositors did lose the right to use the Johannesburg money market, being obliged to hold domestic deposits instead, at generally lower rates of interest. The new central bank held the matching foreign deposits, so that the public sector gained at the expense of the private sector.

The main disadvantage of being in the RMA was the very limited scope for independent macroeconomic policy available to the Botswana Government. Exchange controls, interest rates, the foreign exchange rate, investment of the bulk of foreign exchange reserves were entirely controlled by the South African Government. There was little or no consultation on these issues with the Botswana Government, which also had only minimal control over domestic commercial banks.

The Bank of Botswana was created in 1976. Costs included annual expenses for running the Bank of about one million Pula a year (including depreciation of fixed assets and the cost of the new notes and coins), an addition to the strain on skilled manpower (nearly all the senior management was foreign), and the increased risk of financial mismanagement. The benefits included the availability of new policy instruments, the building-up of financial expertise (although this benefit was reduced by having to rely on expatriates), increased opportunities for innovation in financial institutions, and the transfer to the Bank of Botswana of foreign funds previously held by the private sector. Easily the most important of these advantages was the availability of new policy instruments, although success in using them was dependent in turn on success in building up expertise.

\section{6-1981: The Good Times}

From 1976 to 1981 the Bank of Botswana had a relatively easy time. The balance of payments was mainly in surplus, the reserves rose steadily to more 
than five months c.i.f. imports, the government had on deposit at the Bank of Botswana between 30 and 50 per cent of a year's current revenue, and the commercial banks did not show any signs of expanding their lending too fast. The new exchange control rules were extremely liberal (for a developing country) and most of their administration could safely be left to the commercial banks without fear of dire consequences. The main use of the exchange control rules was to transfer the liquid balances previously held abroad (principally by the commercial banks and the diamond mining company) from private holders to the Bank of Botswana. The exchange control rules also gave the Bank of Botswana some powers of supervision over large loans by the commercial banks, as foreign controlled companies had to get permission to borrow locally more than the money they had brought into Botswana; and there were some limits to the expatriation of capital.

The main efforts of the Bank of Botswana during this period were devoted to trying various ways of getting the commercial banks to lend more money and to lend more of it long term. Botswana interest rates were lowered to keep them below rates in South Africa. Most imports (more than 85 per cent) came from South Africa and therefore a large part of lending was to finance South African imports. It was hoped that more of this business could be done in Botswana if there was a rate differential.

In order to enable or encourage the commercial banks to make more (or even some) longer term loans, the government deposited with them some of its surplus balances at long term, since the banks claimed (irrationally) that they could not lend long out of short term deposits. In addition the government passed a law enabling the commercial banks to take improved security on cattle, the main locally owned asset. And the Bank of Botswana issued only a small number of Treasury Bills, and offered a very low rate of interest to the commercial banks on the remainder of their surplus liquidity. As a result the gap, between what the commercial banks could get on a marginal loan and the return on unlent money rose from about three to about six percentage points.

On the whole, none of these measures worked, or at least there was no evidence that they did. The lending of the commercial banks barely rose for two years, and rose only slowly for the next two - yet it had risen from P $14 \mathrm{mn}$ to $\mathrm{P} 71 \mathrm{mn}$ in the three years before the Bank of Botswana started in 1976. As already noted, the economy was between mining construction booms during the period 1976 to 1979: Selebi Phikwe (coppernickel) was complete, and Jwaneng (diamonds) had not been started. The leading sector was the government itself, and its efforts. held mostly within its capacity to implement projects efficiently, barely maintained the economy on the plateat reached in 1976.

Other monetary policy implemented during this period included diversifying the investment of the rapidly growing foreign exchange reserves, which rose from P65mn in 1976 to P21 $1 \mathrm{mn}$ in 1979 (and P261 mn in mid-1981). Before 1976, the country"s de facto foreign exchange reserves were held by the private sector, nearly all in Rand (plus a small amount of sterling held by the government). The reserves lost value, therefore, whenever the Rand was devalued. Monetary independence gave the Bank of Botswana a chance to diversify the risk by investing in a portfolio of currencies. The Bank also estimated how much of the foreign exchange reserves really needed to be held in short term and therefore lower yielding assets (surprisingly little. since all the possible disaster scenarios were found to take a long time to affect the foreign exchange reserves). Investment policy was fairly successful, no doubt partly from luck and partly from the lack of financial crises to divert management attention.

Exchange rate policy was used to moderate inflation. The Pula was revalued upwards three times, to reduce the impact of South African inflation on domestic prices, especially as they affected lower income groups. Revaluation was estimated to have a benign effect on income distribution in Botswana, since the poor spent more of their cash income on imports than the rich $(70$ per cent against 40 per cent). The poor spent largely on imported basic necessities. while the rich spent significant amounts on locally produced services. Research showed that the benefits of revaluation. at least in times of relatively slack demand, were indeed passed on to the consumer and not retained by traders.

The Bank of Botswana also had the unusual task of preventing the commercial banks from turning away deposits. Because of the perceived lack of investment opportunities. and a requirement concerning the retention of profits to maintain certain capital ratios, the commercial banks began to refuse large additional deposits. If allowed to continue, this would have been bad for the country reputation as a place to do business, and would have encouraged depositors to seek ways of avoiding the exchange control rules on keeping deposits in Botswana. So the Bank of Botswana opened an account for one large mining company, and for a number of parastatals, which enabled the commercial banks to continue accepting deposits from their other customers.

Knowledge of foreign currency markets also helped to improve the quality of advice available to the 
government on foreign borrowing and debt management. Advice on domestic borrowing by the public sector improved with experience. As with some of the other Bank of Botswana activities, advice on borrowing could in principle have been developed without an independent monetary system and an institution to run it, but in practice had not been and probably would not have been.

\section{1-1982 Diamond Crisis: The Bad Times}

In the middle of 1981 the diamond boom finally reversed itself. For the first time in many years De Beers (which sold 85 per cent of the world's gem diamonds and had controlled the price of rough stones) was not only forced to buy into the stockpile (net) but also to impose quotas on producers, including Botswana. Botswana chose to continue full production, and stockpile the unsold stones. At one stage, in late 1981 and early 1982, Botswana sold no diamonds at all for three months. This was extremely serious for the balance of payments, since before the crisis diamonds had grown to represent more than 60 per cent of exports.

To make matters worse, lending by the commercial banks had at last taken off. Stimulated by the construction of Jwaneng: in $198 \mathrm{I}$ bank lending rose by more than 50 per cent, from P96mn to Pl48mn. The foreign exchange reserves fell rapidly, from their peak of P261 mn in mid-1981 to P198mn in March 1982; and it was estimated that without government action they would virtually have disappeared by the end of that year, even using quite optimistic guesses for diamond sales. The only saving feature was that the new diamond mine (Jwaneng) was due to start producing in mid-year, which would increase Botswana's sales quota with De Beers.

The most important single government decision was not to wait to see whether (and when) the diamond market would recover before taking action. It was argued that adjustment might be very much more difficult and costly if the foreign exchange reserves and foreign credit had already been used, since the required adjustment would then be larger and therefore more disruptive, at a time when credit would be harder and thus more expensive to get.

Actual measures taken included the following:

(a) the biannual review of wages, due in early 1982 , recommended a zero increase at a time when price rises since the last review suggested an increase of about 27 per cent;

(b) interest rates were increased, from 10.5 per cent to 14.5 per cent, over 10 months;

(c) the commercial banks were asked to restrict growth in their lending to a figure below the rate of inflation, and the official liquid asset requirement was increased in case they did not comply;

(d) sales tax was introduced for the first time on a number of non-essential goods;

(e) the Pula was devalued by 10 per cent although this only restored its rate against the Rand of a year earlier (the Rand had been slipping down against other currencies by more than the Pula);

(f) the government announced its intention to cut both capital and current expenditure;

(g) the government drew down a previously arranged but unused Eurodollar loan, because the marginal cost of using it if the money were reinvested in the same market (and not spent) was small; the cost was thus very much less than negotiating a new loan at a later date.

Just as significant as the measures taken was what the government did not do: there was no general tightening of exchange controls or import licensing, and no additional foreign borrowing other than the Eurodollar loan already mentioned.

The only changes in exchange controls were a minor reinterpretation of the rules for local borrowing allowed by foreign controlled companies, which had been very generously interpreted during the previous period. Other changes in the exchange control rules were ruled out: it was thought that the business community, which had plenty of experience of draconian exchange controls in neighbouring countries, both black and white ruled, would panic if more drastic changes were made. It was not thought that the Bank of Botswana would be able to control the resulting flight of capital out of the country.

No additional foreign borrowing was undertaken to sustain the foreign exchange reserves, in spite of the lower cost of borrowing at once rather than later. The government expected that it would be even more difficult to hold the line on government spending and lending if the foreign exchange reserves were to rise. The possibility of arranging standby credits as an alternative was discussed, but not pursued.

The government's strategy was to use as many of the available policy instruments as possible, so as to avoid putting too much strain on any one of them. There was some concern that the degree of wage restraint was too severe, and that this would create unmanageable problems later. But the next year's wage award was only eight per cent, comfortably below the 1982 inflation rate of about 13 per cent, so that there was no element of compensation for the fall in real wages in 1982. 
There was no way of knowing, in the case of several of the adjustment measures, whether the main effect would be on the demand for imports, or short term capital movements. Both would have the same effect on the foreign exchange reserves, but the government was concerned that imports should actually be reduced as well as expecting that the measures to make credit scarce and more expensive would shift some borrowing offshore.

Overall it was a very conventional package, so much so that by the time the IMF arrived, in May 1982, agreement was quickly and easily reached. Most of the policy changes that would have been insisted on by the IMF as conditions of a loan had already been implemented. Indeed, the consequences of the government's adjustment measures were already taking effect. The foreign exchange reserves rose rapidly, from a low of $\mathrm{P} 198 \mathrm{mn}$ in March 1982, to P301mn only two mont hs later. As a result, the Letter of Intent to the IMF, the essence of whose terms had been agreed, was never sent.

The very rapid short term rise in the foreign exchange reserves must have been caused by capital inflows; but the maintenance of the reserves at that high level was caused by the other measures, notably the wage freeze which reduced real wages by about 20 per cent in 1982 and 25 per cent in 1983 compared to their 1981 base. Known capital movements (the Eurodollar loan, a switch offshore of some borrowing by the coppernickel mine and the paper gain in the reserves from devaluation) amounted to $\mathrm{P} 7 \mathrm{lmn}$, with a further short term capital inflow of about $P 30 \mathrm{mn}$ in the two months March to May 1982. Imports in 1982 were almost exactly the same as in 1981, much lower than the rate of inflation, and much lower than the 23 per cent rate of increase in the previous year.

The attempt to reduce government spending played only a small part in reducing imports: the rate of growth of current spending fell from 18 and 13 per cent, and the rate of growth of capital spending actually increased. By the time that the expenditure review was taking place the reserves were already recovering, which no doubt reduced the incentive to proceed with unpopular measures.

The main burden of the adjustment programme was borne by the better off urban groups, who were affected by the wage freeze and the cost and scarcity of credit. Devaluation had a greater proportionaí impact on the poor, as already explained; but the devaluation was only a correction of the upward drift of the Pula against the Rand, so that its effect was not as severe as if it had taken place in different circumstances. In any case, the government believed that the cost of failing to adjust quickly and effectively could have been to create the sort of extreme scarcity of foreign exchange and excessive foreign debt which had occurred in other African countries. In those circumstances, the poor suffer most: remote rural clinics run out of drugs, the unskilled lose their jobs, goods are in short supply and the better off tend to get access to the limited supply of basic commodities. The best way of protecting the welfare of the poor was thought to be by avoiding severe macroeconomic imbalance.

\section{Conclusions}

Several conclusions can be drawn from this experience. First, as is well known, monetary policy is like pulling and pushing on a piece of string. It works when the objective is to slow down an expansion, but not if the objective is to get the economy moving during a period of slack aggregate demand. If monetary policy is used to remove the brakes after a period of restraint, then it may be seen to be the cause of expansion, provided of course that frustrated demand survives the period of restraint; but it cannot work on its own.

Second, the conventional package of measures to cut demand was extremely successful in the particular situation facing Botswana at the beginning of 1982 . The essential elements of that situation were that Botswana had not introduced any significant controls on foreign trade and payments, so that imports were determined more or less entirely by income, capital inflows and domestic credit creation. It was therefore simple to reduce the demand for imports by reducing the growth of income and credit - imports induced by capital inflows would be self financing, and therefore of little significance in the short run.

The apparent success of the measures in this case says absolutely nothing about whether they would work in countries which had strict controls on foreign payments. The most that can be said is that conventional adjustment measures would tend to work in a very different way, evn if they were necessary in different circumstances. It was also the case that Botwana could afford not to worry unduly about the mix between reduction in demand and short term capital inflow because of the low external debt service ratio at the time (less than two per cent).

Third, Botswana had enjoyed a period of remarkable growth in real income and employment, as well as exceptionally good prospects for promotion or transfer to better jobs for a wide range of people. A severe cut in real wages and salaries was much easier to implement in such circumstances than if real income had been static or falling for some years.

Fourth, the same argument applies to some extent to bank lending. Local credit had been freely available, 
from the National Development Bank and the government as well as the commercial banks; so borrowers had probably not used easily available sources of foreign credit. They were also more willing and able to finance themselves out of retained profits, than if a tight credit situation had existed for some time.

Fifth, Botswana was internationally creditworthy, so that it was easy to shift borrowing to foreign sources by making domestic credit scarce and expensive. Many other African countries are not so fortunate, even when agreement with the IMF has been reached.

Sixth, Botswana acted fast, not taking the apparently easier option of using the reserves while waiting to see if action could be avoided when and if a recovery occurred in the diamond market. There were even some accusations of overkill, understandable at a time when the sort of commercial and industrial investment that the government had been trying to get going for so long was finally under way. Even in this, the aspect of Botswana's case which owed most to good judgement rather than good luck, the country was fortunate in having to adjust later than most other countries and so having their experiences as a guide.

Finally, the crisis was short lived. Diamond exports, helped by production from Jwaneng, fell to P44mn in the second half of 1981 , from P $123 \mathrm{mn}$ a year earlier; but by the second half of 1982 they were at a new six monthly high of P $141 \mathrm{mn}$. The country's foreign trade deficit fell from P239mn in 1981, to P130mn in 1982; and the overall balance improved from a deficit of P6l mn to a surplus of P57mn. A major component in this rapid turnaround was the recovery of exports to a level slightly higher than before the fall in 1981. In this Botswana was enormously lucky, compared with countries that had to endure the (unexpectedly) severe and prolonged consequences of the post-1979 world recession.

It is unlikely, therefore, that the case of Botswana is of much direct relevance elsewhere in Africa. Nor should it be assumed that external balance can be easily restored by such conventional methods if controls on foreign payments are removed. Evidence from elsewhere in Africa suggests strongly that 'opening up' an economy that has been closed for some time releases an unmanageable demand for foreign currency. There is not only a large accumulation of pent up demand for foreign currency, previously frustrated by controls; there is likely also to be large additional demand, anticipating the return of controls at any moment. In short, removal of controls frequently lacks credibility, at least in developing countries, and especially in Africa. So the status quo ante cannot easily be restored in order to ensure that conventional measures will work.

\section{Notes on Sources:}

1 This article is a much abbreviated version of Charles Harvey, 'The use of Monetary policy in Botswana - in good times and bad' (Discussion Paper 204, IDS, Sussex, 1985). That paper also contains a detailed account of the setting up of the Bank of Botswana and the creation of the new monetary system in 1976, and extensive statistics and references. Its main sources are:

Ablo, Emmanuel and D. J. Hudson, 1983, 'Monetary policy of Botswana' in M. A. Oommen et al. (eds), Botswana's Economy since Independence, Tata McGraw-Hill, New Delhi

Bank of Botswana, Annual Reports: the 1976 and 1977 Annual Reports contain detailed accounts of the changeover from the RMA to an independent monetary system

Colclough, Christopher and Stephen McCarthy 1980, The Political Economy of Botswana: a Study of Growth and Income Distribution, Oxford University Press

Government of Botswana, 1976, Rural Income Distribution Survey, Central Statistics Office

Quarterly Statistical Bulletins: the issue for September 1978 contains an account of the reasons for a reduction in interest rates in August of that year, and of interest rate policy generally

Harvey, Charles, 1980, 'Botswana's monetary independence - real or imagined?', IDS Bulletin, vol 11 no 4, pp40-44

-(ed), 1981, Papers on the Economy of Botswana, Heinemann, London; see especially papers by Lewis on the problems of diamond dependent development, by Hudson on cattle taxation, and also by Hudson on the Southern African Customs Union

Hudson, D. J., 1978, 'The establishment of Botswana's central bank and introduction of the new currency', in Botswana Notes and Records, Volume 10 